NBER WORKING PAPER SERIES

\title{
THE POLITICAL ECONOMY OF THE BUDGET SURPLUS IN THE U.S.
}

\author{
Alberto Alesina \\ Working Paper 7496 \\ http://www.nber.org/papers/w7496
}
NATIONAL BUREAU OF ECONOMIC RESEARCH
1050 Massachusetts Avenue
Cambridge, MA 02138
January 2000

Prepared for the Journal of Economic Perspectives. I thank Peter Diamond, Alan Krueger, James Poterba, Roberto Perotti and, especially, Martin Feldstein for very useful suggestions and Silvia Ardagna for excellent research assistance. This research is supported by a NSF grant to the NBER. I am very grateful to both organizations for their support. The views expressed herein are those of the author and not necessarily those of the National Bureau of Economic Research.

(C) 2000 by Alberto Alesina. All rights reserved. Short sections of text, not to exceed two paragraphs, may be quoted without explicit permission provided that full credit, including () notice, is given to the source. 
The Political Economy of the Budget Surplus in the U.S.

Alberto Alesina

NBER Working Paper No. 7496

January 2000

\begin{abstract}
$\underline{\text { ABSTRACT }}$
Current surpluses in the U.S. have been achieved by a combination of a strong economy, low interest rates, and sharp cuts in defence spending. These surpluses follow a period (the eighties) of rather exceptional budget deficits. This paper investigates the origin, size, and expected future patterns of the U.S. budget balance. It discusses how different political forces may generate alternative fiscal scenarios for the U.S. in the next decade.
\end{abstract}

Alberto Alesina

Harvard University

Cambridge, MA 02138

and NBER, CEPR

aalesina@harvard.edu 


\section{Introduction}

In 1998, the Federal Government of the United States reached a budget surplus, for the first time in 30 years. Many commentators have described this event as a rare and major success.

What is remarkable is not that the U.S. Government has reached a surplus, but that this result is perceived as so "exceptional." In fact, given the unique and very strong expansion of the U.S. economy in the last eight years, and the "peace dividend" due to the end of the cold war, nobody should be overly surprised at the much-improved fiscal balance. The reason why a surplus for the Federal Government appears as so exceptional is that American citizens, like those of many other industrial countries, have become accustomed to large and persistent deficits from the mid seventies onward. In fact, many European countries, which have had a much lower growth than the U.S., and higher interest rates, are still struggling with this legacy of accumulated debts.

While current surpluses should be viewed as relatively "normal", the large budget deficits of the eighties were exceptional. According to the "tax-smoothing" theory (Barro (1979), Lucas and Stokey (1983)), the budget balance should be used as a buffer to allow tax rates to be approximately constant. This theory implies that welfare is maximized if tax rates are held constant ${ }^{1}$. If tax rates are constant, temporary deficits are expected to occur during recessions and periods of exceptionally high spending. Conversely, budget surpluses should be the norm during expansions, like the current one in the U.S, and periods of temporarily low spending, like when a war, (cold or hot) ends. Therefore, the view that the current surpluses are exceptional and offer an opportunity for doing something extraordinary has to be vastly toned down.

\footnotetext{
${ }^{1}$ The theory is based on convex distortionary costs of taxation. An example of such a tax is a proportional income tax in a labor supply model where a representative individual chooses between leisure and consumption. In a fully specified model, general equilibrium effects may lead to non-constant tax rates, although they would still be less variable than fluctuations in spending (see Lucas and Stokey 1993).
} 
The tax-smoothing theory however, does not take into account the political economy of deficits and surpluses. ${ }^{2}$ How to divide the common pool of fiscal revenues, and how to allocate the tax burden is one of the critical political battlefield in every country. The macroeconomic approach to the effects of fiscal policy on the economy often ignores its redistributive effects. The types of redistribution that standard (i.e. nonpolitical economy) macroeconomic models of fiscal policy capture, are those across generations. ${ }^{3}$

If the conflict over how to allocate fiscal resources is taken into account, then the current debate over the surplus becomes hardly surprising. In many respects, this debate is similar to the one on the question of "who should pay for the deficits". In a period of deficit, the conflict is about which taxes should be raised and which spending programs cut; in a period of surpluses, it is the reverse. However, there is an interesting difference between the political economy of surpluses and of deficits. In a situation of fiscal surplus, resources are available to compensate the temporary "losers" of efficient reforms. In many situations, in fact, the short run costs of certain reforms which fall on a vocal minority of the population, may be sufficient to politically defeat the reform. A temporary abundance of fiscal revenues may help circumventing these political blocks.

In particular, in many OECD countries, including the US, pension reforms are the critical fiscal issue of the next decade, with important implications for long-term fiscal balance. The fraction of the current generation that would see its social security benefits reduced, or its contribution increased, often has enough political influence to block social security reforms, particularly those in which the main beneficiaries are future generations. Countries in fiscal stress are caught between a rock and a hard place. On the one hand, they especially need pension reforms to achieve long run fiscal stability. On the other hand, they can hardly afford compensation schemes for the losers and can hardly finance transitional measures. A country in temporary surplus with a long run problem of solvency of its Social Security system is in a more favorable position to overcome

\footnotetext{
${ }^{2}$ For a review of the literature on the political economy of fiscal policy, which departs from the taxsmoothing model and enriches it with redistributive conflicts and political competition, see Alesina and Perotti (1995).

${ }^{3}$ The pathbreaking papers on intergenerational redistribution and public debt are, of course, Diamond (1965) and Barro (1973).
} 
potential vetoes to pension reforms. One can rephrase the same concept in a tax smoothing framework: the current U.S. surpluses are accompanied by a realization that in the not too distant future the Social Security System will either require more funding or a structural reform. Thus, without a welfare and social security reform, future spending is expected to be higher than today. According to tax smoothing, taxes should be increased today, unless reforms are introduced in order to reduce future spending.

Summarizing: The argument of this paper is that the tax-smoothing theory suggests the current surplus should be used to retire debt, and reduce the debt over GDP ratio. In addition, if one links the current surplus to the long run solvency problems of the Social Security System, then, the surplus allows for some richer policy alternatives to only retiring debt. However, the political battle over the surplus may lead to a flurry of uncoordinated tax cuts and spending increases, which might eliminate both the options of retiring debt or linking the surpluses to the Social Security reform.

This paper is organized as follows. Section 2 briefly reviews the fiscal history of the U.S., which lead to the current surpluses and discusses projections for expected surpluses in the future. Section 3 discusses the various possible alternatives concerning the question of "what to do with the surplus". Section 4 concludes this paper.

\section{The History of the Budget Balance in the U.S.}

Figure 1 shows the debt over GNP ratio in the U. S. in the last two hundred years. ${ }^{4}$ The point of this well-known picture is that the basic implications of the "tax smoothing" hypothesis describes very well much of the U. S. fiscal history. The debt/GNP ratio sharply increases during wars and declines after them. Also, as the Great Depression shows, the debt/GNP ratio increases when growth is low or negative: as a result of the Depression, the debt over GNP ratio in the interwar period did not decline as quickly as after the Second World War. The effect of the business cycle on the debt ratio is reinforced if the policymakers follow Keynesian policies, which recommend a tax rate cut or higher discretionary spending in a recession. 
Figure 2 focuses on the post-second war period. It highlights the precipitous downward trend of the debt/GDP ratio, from 122 per cent in 1946 to 32 per cent in 1979. The corresponding figures for the debt held by the public are 109 per cent and 25 per cent. This pattern is briefly interrupted only by recessions, especially the one after the first oil shock and by "local" military conflicts, (Korea and Vietnam). This downward trend, consistent with the tax-smoothing hypothesis, is clearly reversed in the late seventies/early eighties. While the mediocre growth performance in the period 19791982 contributes to the increase in deficit, the rest of the eighties clearly show a radical departure from "tax smoothing". In fact, budget deficits accumulated in a period of peace and of sustained growth. ${ }^{5}$ The debt/GDP ratio increased to 68 per cent in 1995, (50 per cent held by the public): these are the levels of the debt over GDP ratio of the mid fifties, only a few years after the end of the Second World War. In summary, the current surpluses follow a decade (the eighties) of unsound fiscal policy, from the point of view of "tax smoothing".

Today's surpluses have been the result of: 1) the exceptional performance of the American economy since 1991, a performance which has generated a surge of tax revenues; 2) low interest rates; 3) a large reduction in defense spending, as a share of GDP.

Table 1 shows the pattern of various components of spending as a share of GDP and of total revenues. After the cuts in the early eighties, GDP domestic discretionary spending has remained constant (as a share of GDP) from the late eighties onward, while defense spending has fallen from 5.9 per cent in 1988 to 3.2 per cent in 1998, the lowest level of the last 50 years. Given many localized conflicts requiring NATO intervention, today's defense spending may have reached a level that, unfortunately, is hard to reduce much further. Discretionary domestic spending has instead remained constant as a share of GDP, around 3.2 per cent despite various "budget deals" and "spending caps" imposed in the nineties. Mandatory spending, and, especially, spending on entitlements

\footnotetext{
${ }^{4}$ This is the only case in which, because of data availability ratios of fiscal variables are expressed over GNP. Everywhere else in the paper they are expressed in terms of GDP.

${ }^{5}$ Some commentators have argued that the eighties were a period of "war" because this decade marked the final effort to win the cold war. This argument is however quite weak and looks like as an ex post rationalization than an "ex ante" policy plan.
} 
has continued to grow steadily as a fraction of GDP. In particular, Medicare and Medicaid have almost doubled their share of GDP in ten years, as shown in the Table: these two programs combined were 2.3 per cent of GDP in 1988 and are 3.8 in 1998. Reducing the growth of mandatory spending and entitlements is very difficult politically because these programs affect a large fraction of the population and any significant reduction of spending requires a change of entitlement rules. Even in the days of the so called "Reagan revolution" and his welfare cuts, only those programs with relatively specific beneficiaries were reduced, while broad based programs were largely unaffected. ${ }^{6}$

On the revenue side, as pointed out by Munnel (1998), the large surge in fiscal revenues has gone beyond what could be expected even with the strong economy of the nineties. An interesting question, but difficult to answer, is how much of the reduction in the debt over GDP ratio is due to the behavior of the economy (growth rates and interest rates) and how much of it is due to a discretionary fiscal adjustment. The difficulties in answering this question are several. First, the behavior of the economy may be influenced by fiscal policy; therefore, the effect of policy and of the economy cannot be separated. Second, what should be the baseline for a "normal" economy? Third, how one should correct for cyclical effects various items of the budget varies with alternative hypotheses and procedures. In any case, an intriguing comparison is between the US and countries of the Euro area, many of which were going through fiscal adjustments in the nineties. An interesting question is the following: what would have happened to the US budget if the American economy had grown at the same rate of Euroland and had faced the same interest rates? More specifically, using the procedure described by Auerbach (1994) (page 170 eq.9) I have calculated how much bigger should have been the reduction of the primary deficit over GDP ratio in 1993 in order to achieve the 1998 level of the debt over GDP ratio if the spread between the interest rates and the growth in the US had been the same as that of "Euroland". I chose 1993 because this is a turning point when the debt over GDP ratio in the U.S. stopped its growth, and this is the year of the Omnibus Budget Reconciliation Act (OBRA).

\footnotetext{
${ }^{6}$ On this point see several contributions in Alesina and Carliner (1991)
} 
The answer is that in 1993 there should have been an additional permanent reduction in the deficit over GDP ratio of 1.5 percentage point. ${ }^{7}$ Europe was not doing too well in the nineties, so this figure may be an upper bound, but it highlights how much the economy helped the US fiscal improvement. Reduction of 1.5 per cent of deficit over GDP is quite sizable by international standards.

What about the future? For how long will surpluses accumulate? In a series of papers on fiscal adjustments in OECD economies, (Alesina and Perotti (1995b, 1997), Alesina and Ardagna (1997)), I have argued that fiscal adjustments which do not tackle the dynamic of entitlements are not long lasting and tend to be reversed, simply because tax revenues cannot keep up with the growth of mandatory spending. In fact, looking at the international evidence, one of the strongest indicators of whether a fiscal adjustment is long lasting, is the share of the deficit reduction obtained by stopping the growth of entitlements. ${ }^{8}$ In the same spirit, Auerbach (1994) argues that the Omnibus Reconciliation Act (OBRA) of 1993 did not provide a long run "fix" for the budget, but only a five year benefit which would then disappear.

The Congressional Budget Office (1999) has provided a very optimistic forecast on the accumulation of budget surpluses in the next decade. The CBO predicts that surpluses will continue to increase in the next three years, reaching about 3 per cent of GDP in 2009. As required by law, these forecasts are based upon a legal definition of unchanged legislation. However, from an economic point of view these predictions vastly overestimate the surpluses. The $\mathrm{CBO}$ assumes that the spending caps imposed by the Deficit Control Act of 1997 will remain in place and will be fully implemented. Given the "Emergency Spending" 9 that added $\$ 21.4$ billion of dollars to 1999 discretionary spending, the CBO predicts that until 2002 various cuts will compensate for this extra spending. This implies that discretionary spending will have to decline in nominal terms until 2002, falling from 575 billion in 1999 to 568 billion in 2002 (CBO,

\footnotetext{
${ }^{7}$ The average spread between long term real interest rates and the growth rate in the countries that joined the European monetary union is 3.48 per cent; the same spread in the U.S. was 1 per cent. In order to maintain comparability between U.S. and Europe we used OECD (Economic Outlook n.659, June 1999), data for these calculations. More details are available from the authors.

${ }^{8}$ On this point see also Ardagna (1999)

${ }^{9}$ This is the "Omnibus Consolidated Emergency Supplemental Appropriation Act" for 1999.
} 
1999). After 2002, discretionary spending is expected to increase at the rate of inflation. These projections about spending leads to a predicted reduction of discretionary spending from 6.6 per cent of GDP in 1999 to 5.0 in 2009.

It is virtually impossible that the current spending caps will be enforced in a decade of surpluses. First, it is hard to imagine that defense spending can continue to fall at the same rate of the nineties. The "peace dividend" is pretty much a one shot event associated with the collapse of the Soviet Bloc, and defense spending as a share of GDP is about half of what it was in 1988 (Table 1). Therefore, the reduction of 1.6 per cent of GDP in discretionary spending envisioned by the CBO should come largely from cuts in non-defense spending. As shown in Table 1, even in a period of fiscal adjustment, the nineties, this component of spending remained stable as a share of GDP. If defense spending will remain roughly constant as a share of GDP, the predicted cut in discretionary spending would require halving discretionary domestic spending as a share of GDP. This is very unlikely to happen and recent events confirm this impression. In 1999 the additional 21.4 billions of discretionary spending was "the highest level of emergency spending enacted in the 1990s, excluding spending for the Persian Gulf War" (CBO, 1999). As many observers noted many items in this Omnibus Bill were all but emergencies. So called "emergency spending" may very well become the norm, rather than the exception in a period of surpluses, in order to circumvent legal spending caps. To put it differently, the CBO projects into the future a "legislation" which has the nature of a one-shot, unique legislation implemented in a period of fiscal adjustment. In addition, a one shot "peace dividend" is projected into the future.

A more economically meaningful baseline of "unchanged policies" is one in which discretionary spending increases at the same rate of GDP, especially if defense cuts are very unlikely to proceed at the same pace as the last decade. Under this much more reasonable assumption that discretionary spending will remain at the same share of GDP in the next decade, the size of the surplus in 2009 is roughly halved, from 3 per cent of GDP to about 1.5. The CBO also assumes that tax revenue, as a share of GDP will remain roughly constant. Even if fractions of the tax cuts discussed in Congress are passed, this baseline assumption is very optimistic. 
The CBO assumptions about interest payments are, by implication, also quite optimistic. As a share of GDP interest, interest spending is expected to fall from 2.3 in 1999 to 0.6 in 2003. This would be the result of low interest rates and the rapid reduction of the stock of debt. Given the large surpluses that the CBO predicts the debt held by the public is predicted to fall sharply, reaching less than 10 per cent of GDP in 2009. If, as argued above, surpluses will accumulate less rapidly, the stock of debt will decline more slowly and interest payments will remain a higher fraction of GDP than what predicted by the $\mathrm{CBO}$. In addition, the CBO's predictions about interest rates are reasonable, but on the optimistic side. ${ }^{10}$

In summary, under the realistic assumption that discretionary spending will not decrease much as a share of GDP, and that a small tax cut will be implemented in the next few year, the projected surpluses are less than half of the much-publicized forecasts of the CBO. In fact, even half of what the CBO predicts appear as a rather optimistic forecast.

If one considers a time horizon beyond 10 years, the optimism about surpluses have to be toned down even more. As Auerbach $(1994,1997)$ forcefully pointed out, if one considers the effects of the aging generation of the "baby boomers" on Medicare, Medicaid and Social Security, the US budget is, in the long run, in deficit, rather than in surplus; that is, in order to prevent the debt/GDP ratio to increase in the next few decades, one would need an increase in the surplus well beyond the already optimistic predictions of the CBO. As pointed out in Table 1 the rapid growth of Medicare and Medicaid is already happening, the growth of Social Security spending will come soon, as soon as the first "baby boomers" retire.

In summary, this section has made three points: 1) the current surpluses follow a period of significant departure from the prescription of the "tax smoothing" model; 2) there is much uncertainty about the amount of future accumulation of further surpluses, but the latter are very likely to be much smaller, less than half of the predictions of the $\mathrm{CBO}$ for the next 10 years; 3) the growth of spending for Medicare, Medicaid And Social

\footnotetext{
${ }^{10}$ The CBO's predictions on interest rates may be consistent with the hypothesis of a large drop in he government outstanding debt, which may not materialize.
} 
Security, with unchanged legislation, will be a major source of fiscal stress in the next decades.

\section{How to Use of the (Alleged) Surpluses?}

First, I briefly discuss how economic theory would answer the question posed in the title of this section, and then I will analyze the politics surrounding it.

\subsection{The Economics of Surpluses: Implications from theory}

Given the discussion of the previous section, the theorists' answer to the question of what to do with the surplus is simple: retire outstanding debt. As argued above, two arguments support this view: first, debt should be issued in recessions and retired in booms according to tax smoothing; second, current surpluses follow the "excessive" deficits of the eighties.

The argument for a temporary tax cut is very weak, given the current state of the U. S. economy. More generally, the use of discretionary fiscal policy for "fine tuning" is highly questionable, due to the "long and variable lags" argument. An argument for a permanent tax cut should ultimately rely on two grounds:

1) Spending is or it is expected to be permanently lower;

2) Growth is permanently higher, for some "exogenous" reasons, so lower tax rates will generate higher revenues. ${ }^{11}$

I have serious doubts on both assumptions, especially the first. In any event, the point is that an argument in favor of a tax cut should be largely unrelated to the current temporary surplus. In fact, the effect of the retirement of the baby boomers implies an expected increase in outlays for the Government, at unchanged legislation. This effect calls for a permanent tax increase, rather than a tax cut, with unchanged legislation.

\footnotetext{
${ }^{11}$ I do not consider a Laffer curve argument, according to which lower tax rates would produce higher revenues automatically.
} 
Obviously, legislation can change. Therefore, a different and interesting argument suggests using the surplus to finance tax reforms, particularly Social Security reforms. This issue is discussed in detail below.

The criticisms directed to the proposals of using the surplus to cut taxes apply, in reverse, to proposals of spending hikes. Whether or not one favors more domestic spending, it is simply incoherent to argue that the current temporary surplus can support new spending programs, which, regardless of the intentions of the legislators, most often become permanent. Given the structure of the dynamic of spending discussed above, any proposal for more domestic discretionary spending requires a statement about how to finance it, either with higher taxes, or lower spending for entitlements, or more borrowing (i.e. more taxes later) or a combination of the above.

In summary, the argument that because of the current surplus, tax rates should be cut or spending should be increased is very weak from the point of view of economic theory.

\subsection{The Politics of Surpluses}

In many respects, the political economy of surpluses is similar to the political economy of deficits. In both cases, various lobbies, factions, pressure groups, and their representatives fight over the allocation of the costs of adjustment (in the case of deficits) or the benefits of the common pool of resources (in the case of surpluses) ${ }^{12}$. In different countries and in different points in time, political institutions are more or less capable of coordinating these pressures into a coherent and sound fiscal policy.

The academic literature has pointed out that the "fragmentation" of a political system is an obstacle to the implementation of the appropriate fiscal decisions, particularly when various shocks require a swift fiscal response. In the most general sense, political fragmentation is a situation in which many political groups have a "voice" in fiscal decisions, and many have veto power. ${ }^{13}$ The point is not that fragmentation

\footnotetext{
${ }^{12}$ For a discussion of political models of fiscal adjustments see Alesina, Perotti and Tavares (1998)

${ }^{13}$ For theoretical work on this part, see Alesina and Drazen (1990). For empirical work on a cross section of countries, see Roubini and Sachs (1988) and Perotti and Kontopoulos (1998)
} 
necessarily creates deficits, but that fragmentation creates obstacles to policy changes, because it makes more difficult to reach agreements about corrective fiscal packages.

For example, the British political system is relatively non-fragmented, since, by design, the same party controls the executive and the legislature. Interestingly, despite the less than stellar economic performance of the second World War, the U. K. is not a country with a debt problem. This country at the end of the Second World War had a debt over GDP ratio of more than 250 per cent. Currently it is around 60 per cent, one of the lowest in Europe, and the UK was not one of the countries in danger of not making the fiscal criteria for joining the European Monetary Union, although this country opted out. On the other extreme, countries with large and fragmented coalition governments have not managed to quickly adjust to the shocks of the seventies, and have accumulated very large debt. The best examples are Belgium and Italy, two countries with a fragmented political system. These countries' debt over GDP ratios are currently more than 120 per cent and these two countries were almost not admitted in the European Monetary Union because of their poor fiscal performance.

Divided government is the U. S. version of the coalition governments of parliamentary democracies and it has been often regarded as an obstacle to a smooth implementation of sound fiscal policies. ${ }^{14}$ The evidence on this at the federal level is, however, inconclusive. While several observers ${ }^{15}$ have attributed the deficit of the eighties to a fiscal deadlock caused by divided government, other periods of divided government have not produced similar outcomes. Evidence gathered at the state level, thanks also to the larger sample, provides information that is more reliable. In particular, Poterba (1994) and Alt and Lowry (1994) show that states with divided governments have delayed the adjustment to negative fiscal shocks relative to states with unified governments. What is especially interesting for the present the paper is that both articles find that even positive fiscal shocks (i. e. unexpected higher tax revenues) have created

\footnotetext{
${ }^{14}$ Divided government is defined as any situation in which the same party does not hold the Presidency, the House of Representatives, and the Senate. See Alesina and Rosenthal (1995) for a theoretical and empirical discussion of divided government in the U.S.

${ }^{15}$ See, for instance, McCubbins (1991).
} 
fiscal deadlocks and delayed legislation in states with divided governments. ${ }^{16}$ This finding hints that the "politics" of deficits and surpluses are similar. In both cases, negative or positive fiscal shocks generate a similar political battle: who should pay for the deficits in one case, and who should benefit from the surpluses in the other. In summary: the nineties provided very favorable fiscal "shocks": growth of revenues, low interest rates and the "peace dividend". Now the battle is open on how to allocate the fiscal harvest of the nineties.

An interesting question is whether in a situation of divided government, which is becoming more and more the rule rather than the exception in the US, these battles over the budget are more or less likely to result in what Niskanen (1997) labeled "an incoherent mishmash of small spending increases and tiny tax cuts". First, neither of the two American parties is immune from "pork barrel" politics. To same extent the "balance" provided by divided government may help avoid the most egregious deals. On the other hand, divided government may create an obstacle to the adoption of a coherent fiscal plan, if the latter is the result of a badly worked out compromise between conflicting plans of the Administration and of Congress, not held by the same party. In other words, relative to unified government, divided government offer more moderation and cheeks and balances, but also it creates the risk of fiscal confusion, a proliferation of uncoordinated bills leading to a waste of the temporary surplus without addressing the long run fiscal deficits of the Social Security System. The early stages of the discussion of what to do with the surplus show elements of both aspects, the positive and the negative, of divided government. Both parties have kept doors open to pork barrel politics. The emergency-spending package of 1999 included several items that can hardly be considered "emergencies". The recent debates in Congress are another example of a series of proposals for "favors" to various constituencies. ${ }^{17}$ On the other hand, the extreme proposals on each side of the political spectrum will face opposition in one of the two branches of government, if the latter is "divided". A Democratic President would veto the most extravagant tax cutting proposals from a Republican House. If the former

\footnotetext{
${ }^{16}$ The effect of divided government on the "delay" in reducing surpluses is, however, smaller than the "delay" in reducing deficits.
} 
wanted to spend the surplus in domestic programs, as if there were no tomorrow, a Republican House might object.

Beyond the standard battle over "pork barrel" favors, a few general themes about the use of the surplus have taken shape. Three kinds of general proposals have emerged:

\section{1) Cut taxes across the board.}

Republicans in the House and the Senate have been pushing for major tax cuts, the biggest since those of the first Reagan's administration. These cuts range from very broad based ones, like proportional reduction on income tax rates, to more specific items of the tax code, like the inheritance tax. The philosophy underlying these proposals is that even through the first best fiscal policy may call for retiring debt, current or future Democratic legislators and Presidents are likely to spend the surplus in "wasteful" domestic programs, if surpluses materialize. Thus, given this political constraint, the second best policy for a fiscal conservative is to reduce fiscal revenues available to big spenders.

This idea cannot be easily dismissed, if one looks back at the eighties. The "Reagan deficits" of the early eighties materialized for a variety of reasons vastly discussed by many, and that we cannot review here ${ }^{18}$. The bottom line is that that the Reagan plan of tax cuts and spending reductions accomplished both but the former more than the latter, giving raise to a deficit spiral. Once the deficits materialized the Republicans both in the Administration and in Congress held their ground against major tax increases. Many observers noted that in the end the deficits would have imposed a binding constraint on spending, an outcome non-disliked by many conservatives. A similar view briefly reemerged during the Dole campaign of 1996.

From the point of view of someone who believes that "government is too big," the policy of cutting taxes in order to "force" spending cuts in the future, is reasonable, if

\footnotetext{
${ }^{17}$ For a humorous descriptions of some of the pork barrel proposals discussed in Congress see several issues of The Economist in July-August 1999.

${ }^{18}$ See, in particular the contributions by Poterba, Stockman and Shultze in Feldstein (1994)
} 
not pushed to excess. Alesina and Tabellini (1990) provide a model consistent with this implication. A "conservative" policy maker, opposed to the growth of domestic spending programs, may choose to abandon fiscal balance and let public debt accumulate. Future "liberal" governments will have to use a relatively large fraction of tax revenues to service the debt and they will be limited in the amount of tax revenues they can use for domestic spending. From the point of view of the conservative government, the cost of abandoning tax smoothing is more than compensated by the constraint imposed on domestic spending. More generally, if one believes that institutional failures lead to spending biases, then a policy of tax cuts balances this distortion.

The "Reagan's deficits" of the eighties certainly contributed to a subsequent reduction of the size of government, measured as non-interest spending over GDP. If the Clinton administration did not face a deficit problem, spending caps would have not been imposed. It is quite likely that discretionary spending would have not remained constant as a share of GDP during the Clinton Administrations, if the latter did not have to balance the budget and did not have to use a relative large fraction of fiscal revenues to service the debt accumulated in the eighties. In other words, the argument that "if fiscal resources are available, they are spent" implies, logically, that the only way of enforcing spending cuts is to lower taxes. This is the "Starve the Leviathan" policy.

The Achilles' heel of these proposals is that, realistically, the only way to significantly cut spending in the long run is to do something about Social Security. Many Republicans advocates of major tax cuts are not in the front line amongst the advocates of cuts of Social Security benefits.

The current proposals of the Administration do not show a tendency to large increase in discretionary spending (remember, however, the 21.4 billion "emergencies" for 1999). However, conservatives argue that after a display of "moderation" in an election year, the true spirit of the big spending Democrats will resurface. The idea of restraint of spending in election years is exactly the opposite prediction of the traditional "political business cycle" of Nordhaus (1975). This observation simply shows that the Nordhaus' model offers only a very narrow view of the political process. In fact, the Democratic Party, sensitive to accusations of lack of fiscal restraint is moving toward the 
political middle of the road in the pre election period on fiscal issues. ${ }^{19}$ Republicans argue that it will not last.

II) Use the surplus to finance more discretionary domestic spending.

This proposal, although not explicitly advocated by the administration has considerable support; see for instance, Reich (1999), Eisner (1998) and Baker (1998). In particular, these authors, amongst others, favor the use of surpluses to finance public investments in education, infrastructure etc. Given the budget arithmetic discussed above, the view that many resources are available to increase domestic spending without raising taxes is simply incorrect. In fact, the argument for using current (temporary) surpluses to finance permanent spending hikes has the same flaws of the argument for permanent tax cuts.

It may very well be correct that current levels of spending in education, infrastructure, poverty alleviation programs etc. are too low. This does not mean that they can be increased without either cutting some other forms of spending, or by increasing taxes today or in the future, issuing debt today. Advocates of more discretionary spending are not amongst those who favor cuts in entitlements, and almost nobody in the US seems to favor higher taxes, at least openly.

Proponents of the "increase spending" argument may, in fact, be perfectly aware of the budget arithmetic, but they may have in mind the reverse of the "Starve the Leviathan" argument. They hope that once in place new spending programs will create constituencies, who favor them so that the fiscal resources necessary to finance them will be found, sooner or later.

\footnotetext{
${ }^{19}$ For models consistent with the view that parties display "moderation" in election years and then if
} 
III) Use the surplus to finance Social Security reforms.

In the most general terms, the argument is very simple. Any reform of the Social Security system, which moves it from a "pay as you go" system to a "fully funded" one, implies transitional costs for the current generation. Using Diamond's (1999) words "significantly improving the financial value of Social Security for future generations would come at the costs of worsening the financial value of Social Security for current generations or would require that general revenues be devoted to Social Security" (page 4). A "social planner" would optimally trade-off the costs for the current generation against the benefits for the infinite future, but in all political systems, the current generation has more "voice" than the future, unborn one. This is not the place to discuss in any detail alternative proposals for Social Security reform; on these issues, see Diamond (1999). The concern, here, is simply to sketch different implications for the budget surplus.

On one extreme of the range of proposals like the one of the current Administration is one that essentially maintains the current "pay as you go" system and simply increase the "advance funding" in anticipation of future solvency problems. In fact, by 2013, the costs of Social Security will begin to exceed payroll revenues and by 2032, the current Trust Fund would be bankrupt, at unchanged legislation. Critics of this proposal argue that "there is a significant chance that some future Congress would use at least some of the funds to increase benefits or reduce taxes or possibly spend them for other purposes" (Diamond, 1999 page 99). Note that this is the same logic underlying tax cuts proposal, namely the logic of "Starve the Leviathan". In fact, on the Republican side, critics argue that the President's proposal for "saving Social Security" is a ploy

elected, show their "true" nature, see Alesina and Rosenthal $(1195,1999)$. 
engineered by the Administration to collect more revenues and avoid scaling down the size of government. ${ }^{20}$

One could pass legislation geared toward preventing the use of the Trust Fund for other purposes, but this kind of "binding" legislation can often be circumvented, at least up to a point. One example of this type of legislation would be a complete separation of the Social Security Budget from the rest of the budget, as advocated, for instance, by Munnell (1998). This may avoid using the Social Security surplus for discretionary spending, but it would not avoid increasing social security benefits for current generations of voters, at the expense of future generations.

An alternative type of proposal is to use the current surplus to finance the transition to a broader adoption of personal retirement accounts, of the $401 \mathrm{~K}$ type. Feldstein and Samwick $(1997,1999)$ and Feldstein $(1999 b)$ have put forward a specific proposal along this line. The idea is that individuals would receive a 2.3 per cent tax $\mathrm{cut}^{21}$ on the condition that the tax cut is saved in a Personnel Retirement Account (PRA). When the individual reaches retirement age, he or she can withdraw payments from his or her PRA. Individuals' Social Security benefits would be replaced by 75 cents for every dollar of PRA withdrawal. Feldstein and Samwick (1999) calculate that financing this scheme would cost about 0.9 per cent of GDP in tax revenues, "less than the currently projected budget surpluses" (page 3). Actually, with the more realistic projections about the surplus discussed in Section 2 of this paper, the cost of this scheme may come close to exhaust all the available surplus. The proponent are well aware of that since Feldstein (1997) noted, "if the near term surpluses are too optimistic, the PRA tax credits could push the budget into deficits". In any case, even in the most optimistic scenario, a temporary tax increase will be needed at some point to finance the full transition to PRA accounts. From a tax smoothing point of view, a temporary deficit

${ }^{20}$ For a specific discussion and criticism of the Administration's plan for Social Security see Feldstein (1999a).

${ }^{21}$ This would apply only up to the Social Security earning limit, currently around $\$ 68,000$. 
incurred to help finance a future large increase in spending is appropriate, especially if the temporary deficits also serve the purpose of reducing future outlays.

Leaving aside a broader discussion of the pros and cons of individual retirement accounts, this type of reform would create more solid commitment to use the surplus to "save Social Security" than simply increasing the Trust Fund. In addition, this kind of proposal may be politically palatable, since it combines an element of tax cut, favored by many Republicans, with an element of "using the surplus to save Social Security", an argument favored by the Administration. A standard criticism is that individuals may reduce other sources of savings if they receive this tax cut linked to forced savings. The reply of the proponents is that the saving rate of the recipient of this scheme is so low already that it is unlikely to offset the forced saving induced by the scheme. Also they argue that the change in the time profile of disposable income may actually increase savings.

\section{Conclusions}

I shall try to summarize a few key implications of the previous discussion.

1) Current surpluses have been achieved thanks to a combination of an exceptionally strong economy, low interest rates and large cuts in the defense budget as a share of GDP. The growth of entitlements has not been stopped.

2) The achievement of a budget surplus will continue to create a flurry of "pork barrel" proposals for tax cuts and spending increases.

3) Even in the most optimistic scenarios on how Congress and the President will coordinate these demands, the surpluses in the next decade are likely to be much smaller, probably less than half, than what actually predicted by the $\mathrm{CBO}$, with unchanged legislation. 
4) Considering the long run evolution of Social Security, Medicaid and Medicare, current surpluses will soon disappear, at unchanged legislation.

5) From a purely "economic" point of view, an optimal use of these surpluses is to retire debt and help a Social Security reform.

6) Using the surplus to finance a transition toward a larger use of individual retirement accounts is more likely to commit revenues to "save Social Security".

7) Arguments for widespread tax cuts are economically unsound, except if one believes that the American system of government is heavily biased toward excessive spending.

8) Arguments according to which current surpluses can finance more discretionary spending are misleading. Even if more investments that are public are desirable, they require a tax increase either today or in the future, or a reduction of spending for entitlements. 


\section{References}

Alt, James and Robert Lowry 1994. "Divided Government, Fiscal Institutions and Budget Deficits: Evidence from the States" American Political Science Review. 88:4, pp. 811-24.

Alesina, Alberto and Guido Tabellini 1990. "A Positive Theory of Fiscal Deficits and Government Debt" Review of Economic Studies. 57:3, pp. 403-414.

Alesina, Alberto and Howard Rosenthal 1995. Partisan Politics, Divided Government and the Economy. Cambridge: Cambridge University Press.

Alesina, Alberto and Howard Rosenthal 1999. "Polarized Platforms and Moderated Policies with Checks and Balances" Journal of Public Economics, Forthcoming.

Alesina, Alberto and Roberto Perotti 1995. "The Political Economy of Fiscal Policy" IMF Staff Papers. March, pp. 1-31.

Alesina Alberto and Silvia Ardagna 1997. "Tales of Fiscal Adjustments" Economic Policy. 27, pp. 487-546.

Alesina, Alberto, Roberto Perotti and Jose Tavares 1998. "The Political Economy of Budget Deficits" Brooking paper on Economic Activity, n.1, pp. 197-266.

Ardagna, Silvia 1999. "Fiscal Adjustments: Which One Works and Why" Boston College, Unpublished.

Auerbach, Alan J. 1994. "The US Fiscal Problem: Where We Are, How We Got Here, And Where We Are Going" NBER Macroeconomic Annual. W4709, pp. 141-75.

Auerbach, Alan J. 1997. "Quantifying the Current U.S. Fiscal Imbalance" NBER Working Paper. W6119.

Baker, David 1998. "The Great Surplus Debate: Invest it" The American Spectator. May-June, pp. 83-86.

Barro, Robert J. 1974. “Are Government Bonds Net Wealth?" Journal of Political Economy. 82:6, pp. 1095-1117. 
Barro, Robert J. 1979. "On the Determination of Public Debt" Journal of Political Economy. 87:5, pp. 940-71.

Congressional Budget Office (1999) "The Economic and Budget Outlook: Fiscal Years 2000-2009" Washington DC.

Diamond, Peter A. 1965. "National Debt in a Neoclassical Growth Model" American Economic Review. 55:5, pp. 1126-50.

Diamond, Peter A. 1999. Issues in Privatizing Social Security: Report of an Expert Panel of the National Academy of Social Insurance. Cambridge: MIT Press.

The Economist (1999) "Who's not for tax cuts" July 17, pp. 23-24.

The Economist (1999) "The Tax-Cutters' Song” August 7, pp. 21-22.

Eisner, Robert 1998 "The Great Surplus Debate: Understand it" The American Spectator. May-June, pp. 86-87.

Feldstein Martin. 1994a (ed.) American Economic Policy in the Eighties University of Chicago Press and NBER

Feldstein, Martin 1994b. "Comments on Auerbach" NBER Macroeconomic Annual, pp. 175-81.

Feldstein, Martin 1997. "Do Not Waste the Surplus" Wall Street Journal. November 17.

Feldstein, Martin and Andrew Samwick 1997. "Potential Effects of Two Percent Personnel Retirement Accounts” Tax Notes. May, pp. 615-20.

Feldstein, Martin 1998. "How to Save Social Security" New York Times. July 27.

Feldstein, Martin 1999a. “Clinton's Social Security Sham" Wall Street Journal. February 1.

Feldstein, Martin 1999b. "Protecting Retirement Income" Testimony before the Senate Finance Committee. March 16.

Feldstein, Martin and Andrew Samwick 1999. Maintaining Social Security Benefits and Tax Rates through Personnel Retirement Accounts: An update based on the 1998 Social Security Trustees Report. NBER Working paper (updated version available electronically at www. NBER.org) 
Lucas Jr., Robert E. and Nancy L. Stokey 1983. "Optimal Fiscal and Monetary Policy in an Economy Without Capital" Journal of Monetary Economics. 12:_, pp. 5594.

Mc Cubbins, Matthew 1991. "Party Governance and US Budget Deficits: Divided Government and Fiscal Stalemate" in Politics and Economics in the Eighties. Alberto Alesina and Geoffrey Carliner, Eds. Chicago: U. of Chicago Press.

Munnel, Alicia 1998. "The Great Surplus Debate: Save it" The American Spectator. May-June, pp. 80-83.

Niskanen, William 1997. "Use a Pending Budget Surplus Only for Major Fiscal Reforms" Congressional Testimony to the House Budget Committee.

Nordhaus, William D. 1975. "The Political Business Cycle" Review of Economic Studies. 42:2, pp. 169-190.

Poterba, James 1994. "State Responses to Fiscal Cases: "Natural Experiments" for Studying the Effects of Budget Institutions" Journal of Political Economy 102:4, pp. 799-821.

Reich, Robert 1999. "The Other Surplus Option" New York Times. August 11. 
a

矛总

m

善若

ด. ํำ

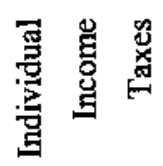

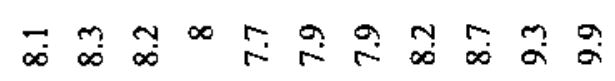

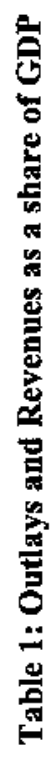

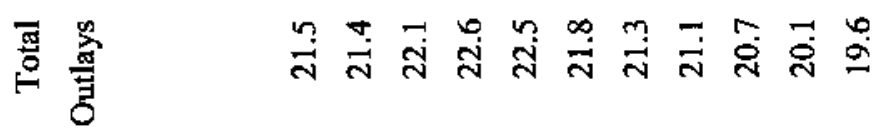

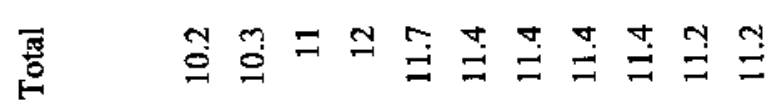

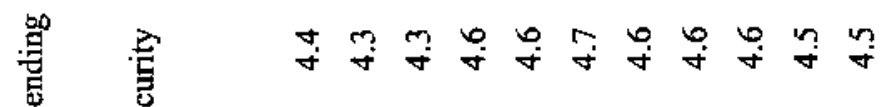

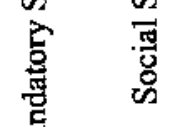

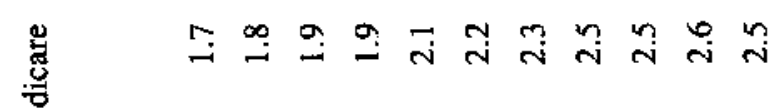

吾离

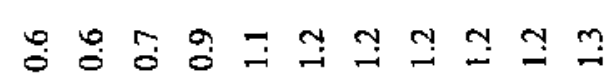

怨

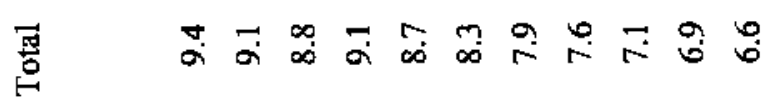

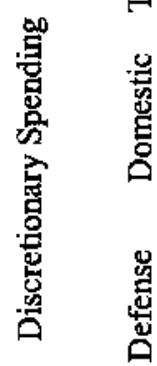

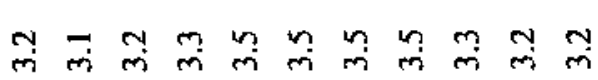

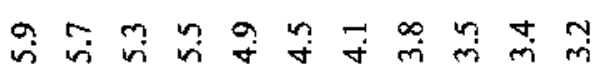

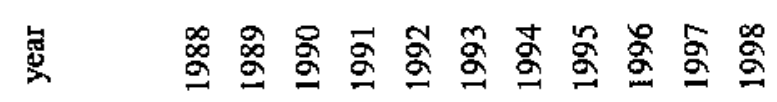




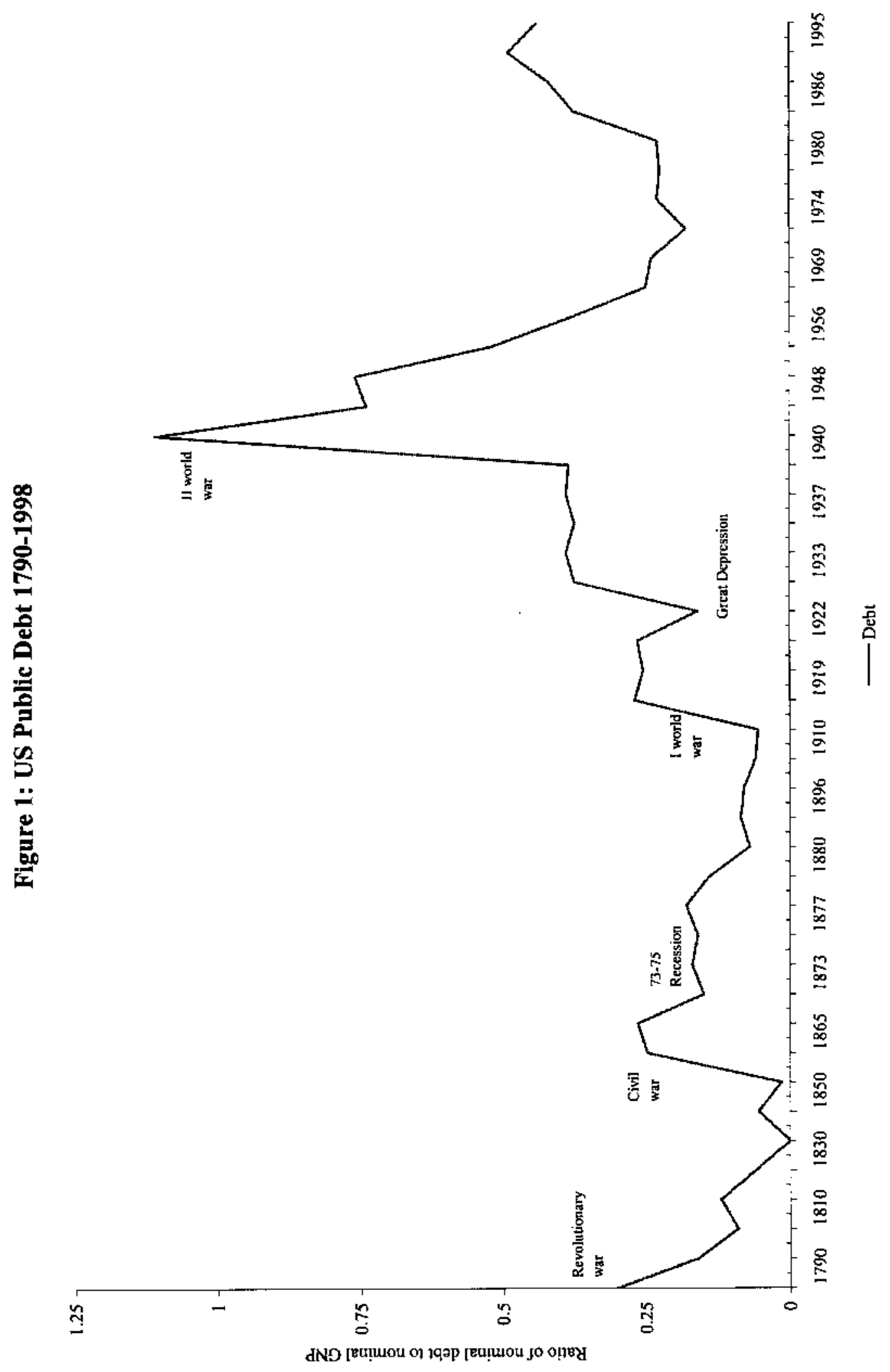


ก

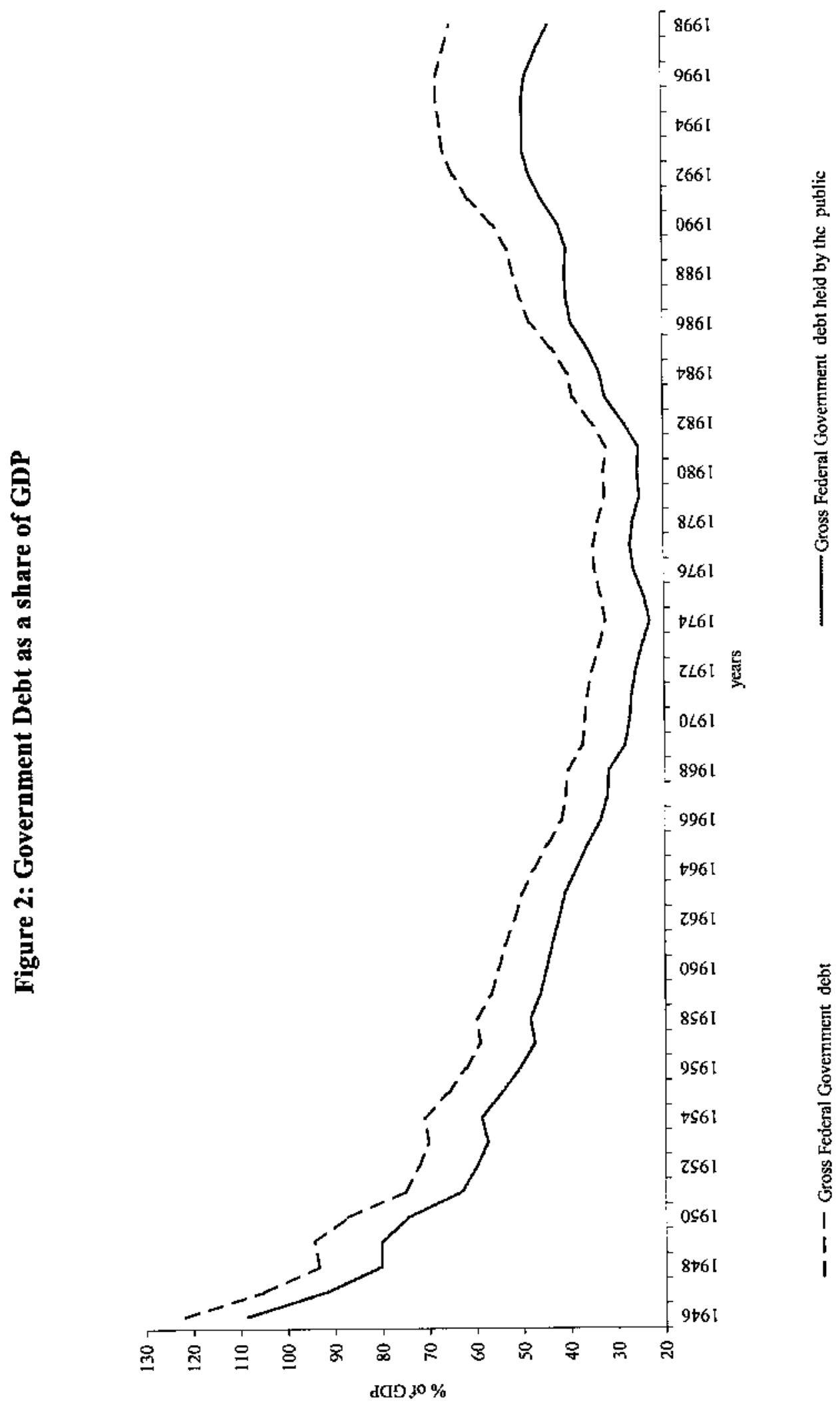

